\title{
Technique proposition and material comparison for surgery rope making
}

\section{Lucas Krusch Bello ${ }^{*}$ (i) Fabrício Guedes Godoy ${ }^{2}$ (D) José Pedro Marquezan de Oliveira $^{3}$ (i)

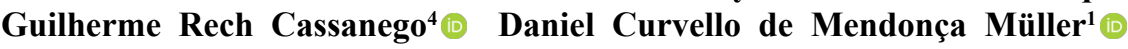

${ }^{1}$ Programa de Pós-graduação em Medicina Veterinária, Universidade Federal de Santa Maria (UFSM), 97105-900, Santa Maria, RS, Brasil. E-mail: lucas krusch bello@hotmail.com. "Corresponding author.

${ }^{2}$ Departamento de Clínica de Pequenos Animais, Centro de Ciências Rurais (CCR), Universidade Federal de Santa Maria (UFSM), Santa Maria, RS, Brasil.

${ }^{3}$ Laboratório de Materiais de Construção Civil, Centro de Tecnologia, Universidade Federal de Santa Maria (UFSM), Santa Maria, RS, Brasil. ${ }^{4}$ Curso de Medicina Veterinária, Centro de Ciências Rurais (CCR), Universidade Federal de Santa Maria (UFSM), Santa Maria, RS, Brasil.

ABSTRACT: The most tension resistant, nonmetallic, surgical suture is 5 polyester. Comparing it's resistance to those of the dogs' cranial cruciate ligament and the canine gastrocnemius tendon's up until they rupture, it's possible to detect a considerably inferior resistance on the implant's part. With the goal of achieving high mechanical resistances from sutures, these were grouped and twisted, resulting in a surgical rope that is adjustable to the patients needs. We analyzed manufacturing methodology, final conformation and tension resistance, based on three sutures models: " $A$ " (1 polyglactin 910), " $B$ " (1 polyester) and " $C$ " (5 polyester). Considering averages of thickness and final load, the " $B$ " implants obtained lower values than " $A$ ", indicating that polyglactin 910 ropes are more resistant than those of polyester. Moreover, the " $C$ " implants resulted in the highest values of load and thickness, indicating that final thickness is predictive towards tension resistance. Size 1 Polyester was the only one to generate linear regression for supported load, ensuring the 25,34 Newtons (N) increment to every suture added to the implant, which suggests its use for the creation of non absorbable ropes. The use of 1 polyglatctin 910 promotes load averages superior to 1 polyester; therefore, it is indicated for making absorbable surgical ropes.

Key words: implant, ligament, polyester, polyglactin 910, tension.

Proposição de técnica e comparação de materiais para confecção de corda cirúrgica

RESUMO: O fio cirúrgico não metálico com maior resistência à tração é o poliéster $n^{\circ} 5$. Comparando a sua resistência com a do ligamento cruzado cranial de cães e do tendão gastrocnêmico canino até suas rupturas, é possivel perceber uma resistência consideravelmente inferior da parte do implante. Com objetivo de alcançar grandes resistências mecânicas a partir de fios de sutura, estes foram agrupados e torcidos, resultando em uma corda cirúrgica ajustável de acordo com a necessidade do paciente. Foram analisadas a metodologia de confecção, a conformação final e a resistência à tração, baseados em três modelos de fios: “ $A$ ” (poliglactina $\left.910 n^{\circ} 1\right)$, " $B$ ” (poliéster $\left.n^{\circ} 1\right)$ e “ $C$ ” (poliéster $n^{\circ} 5$ ). Considerando as médias de espessura e carga final, os implantes " $B$ " obtiveram menores valores do que " $A$ ", indicando que cordas de poliglactina 910 são mais resistentes que as de poliéster. Ademais, os implantes " $C$ " resultaram nos maiores valores de carga e espessura, indicando que a espessura final é preditiva para resistência à tração. O poliéster $n^{o} 1$ foi o único a gerar regressão linear para carga suportada, garantindo o incremento de 25,34 Newtons (N) a cada fio acrescido ao implante, o que sugere seu uso para criação de cordas não absorvíveis. A utilização da poliglactina $910 n^{\circ} 1$ promove médias de carga superiores ao poliéster $n^{\circ} 1$, portanto, é indicada para confecção de cordas cirúrgicas absorvíveis.

Palavras-chave: implante, ligamento, poliéster, poliglactina 910, tração.

\section{INTRODUCTION}

In veterinary medicine, surgical techniques using synthetic ligaments are attracting researchers' and clinics' attention. The prosthesis' objective is to allow the earlier leaning on the limb in comparison with the autograft or allograft, being capable of resisting higher mechanical loads and guaranteeing joint stability (OMINI et al., 2018). In prospective analysis of the use of polymer based synthetic ligament for replacing cranial cruciate ligament in 42 dogs, one can observe that the needed stability wasn't reached in 7 animals in the $4^{\text {th }}$ week after the surgery and 18 animals in the $24^{\text {th }}$ (BARNHART et al., 2006).

However, in mechanical tests of synthetic implants for chronic rupture in the gastrocnemius 
tendon in dogs, favorable mechanical results were observed, such as those of the normal gastrocnemius tendons (MORTON et al., 2015).

Analyzing clinical situations like cranial cruciate ligament ruptures in dogs, we know that they endured $48,07 \mathrm{~N} \pm 0,41$ by kilogram weight until the rupture (MÜLLER et al., 2014) and the average load supported by ligament is $648,31 \mathrm{~N}$ (BRENDOLAN et al., 2001).

However, the gastrocnemius tendon is capable of enduring 1031,3 $\mathrm{N} \pm 317,6$ (JOPP \& REESE, 2009). Parallel to this, the most resistant nonmetallic surgical suture is 5 polyester, supporting a load of 60,43 N (ABNT, 2003).

Based on the concept of friction, it's possible to twist overlapping sutures and neutralize the shearing of a suture over the other, configuring, then, a rope. The final conformation of the rope must respect hierarchical tree, and can be made up of three legs. The twisting raises the contact between sutures, increasing transversal pressure, which maintains the structure and rope continuity of the rope. Transversal forces in the radial direction are responsible, also, for compacting it's interior, reducing empty spaces between the bundles (PAN \& BROOKSTEIN, 2002; YILMAZ et al., 2007).

The direction of twist applied in each component of the rope is alternated. With this, it's possible to improve material accommodation and its final mechanical resistance. Based on this dynamic, various rope configurations are obtained, which can vary according to the goal for which it's made(MCKENNA et al., 2004). Believing in the idea of grouping sutures in order to reach higher resistances, the objective of this study was to present the method for making surgical ropes from sutures, allowing the confection, according to the needs of the patient, of highly tensile resistant implants during the transoperatory period. Due to the lower memory of multifilament suture, only these were compared. The absorbable and non absorbable multifilament samples tested were Polyglatin 910 and Polyester respectively. The thickest available Polyester is 5 Polyester and Polyglactin 910 is 1 Polyglactin 910 (ABNT, 2003).Polyester shares at least one feature with each of these two.

\section{MATERIALS AND METHODS}

Ropes were made from surgical sutures, and for that, only the basic surgical instruments were used, allowing implant creation during the transoperatory period. The sutures used were 1 polyglactin 910 (A), 1 polyester (B) and 5 polyester (C).
The surgical ropes were divided into nine groups, each one identified by a letter and a number, matching the material and amount of sutures used, respectively. They were: Group A9 (nine 1 polyglactin 910 sutures), A12( twelve 1 polyglactin sutures), A15 (fifteen 1 polyglatin sutures), B9 (nine 1 polyester sutures), B12 (twelve 1 polyester sutures), B15 (fifteen 1 polyester sutures), C9 (nine 5 polyester sutures), C12 (twelve 5 polyester sutures) and C15 (fifteen 5 polyester sutures). Each group was composed of three samples, adding up to 27 tested implants.

For standardizing, every suture was sectioned at a 17 centimeters $(\mathrm{cm})$ size. This way, a $70 \mathrm{~cm}$ suture was subdivided in four sutures, leaving a safety margin of two centimeters for the process of sectioning the tips.

The rope making process was based on a pilot study. To start, two hemostatic Crile forceps fixed one of the ends of all the sutures together. For that, the forceps were positioned in the opposite direction from one another, easing their handling during the rope making. This end was named the "Anchor End" and its creation is the first step in the making of all ropes (Figure 1a).

Conversely, the total amount of sutures per implant was divided in three bundles, and each bundle tip was held together by a Crile forceps. This originated the three legs of the rope. Implants with nine, 12 and 15 sutures had their legs composed of three, four and five sutures, respectively. This end was called the "Leg End" (Figure 1a).

After defining the ends of the implants began the twisting step, which was timed. The three forceps on the leg end were twisted in isolation around their own axis with 15 complete rounds, one after another, in the same direction (standardized in this study as clockwise to the leg end forceps manipulator). The anchor end stayed still. During the twisting, tension was exerted continuously between the leg and anchor ends, thus, minimizing the chance of making irregularly twisted legs.

Afterward, the anchor end was twisted counterclockwise to its forceps manipulator, while the leg end was still. It was twisted 15 complete rounds around the implant axis, respecting the continuous tension between the ends during the process. To avoid losing implant length, ligature was done immediately before the forceps were opened and removed. With this, the rope making process is done (Figure 1b). Every implant was made by the same pair of researchers.

With the help of a caliper, each rope's thickness was measured in millimeters $(\mathrm{mm})$ in three 


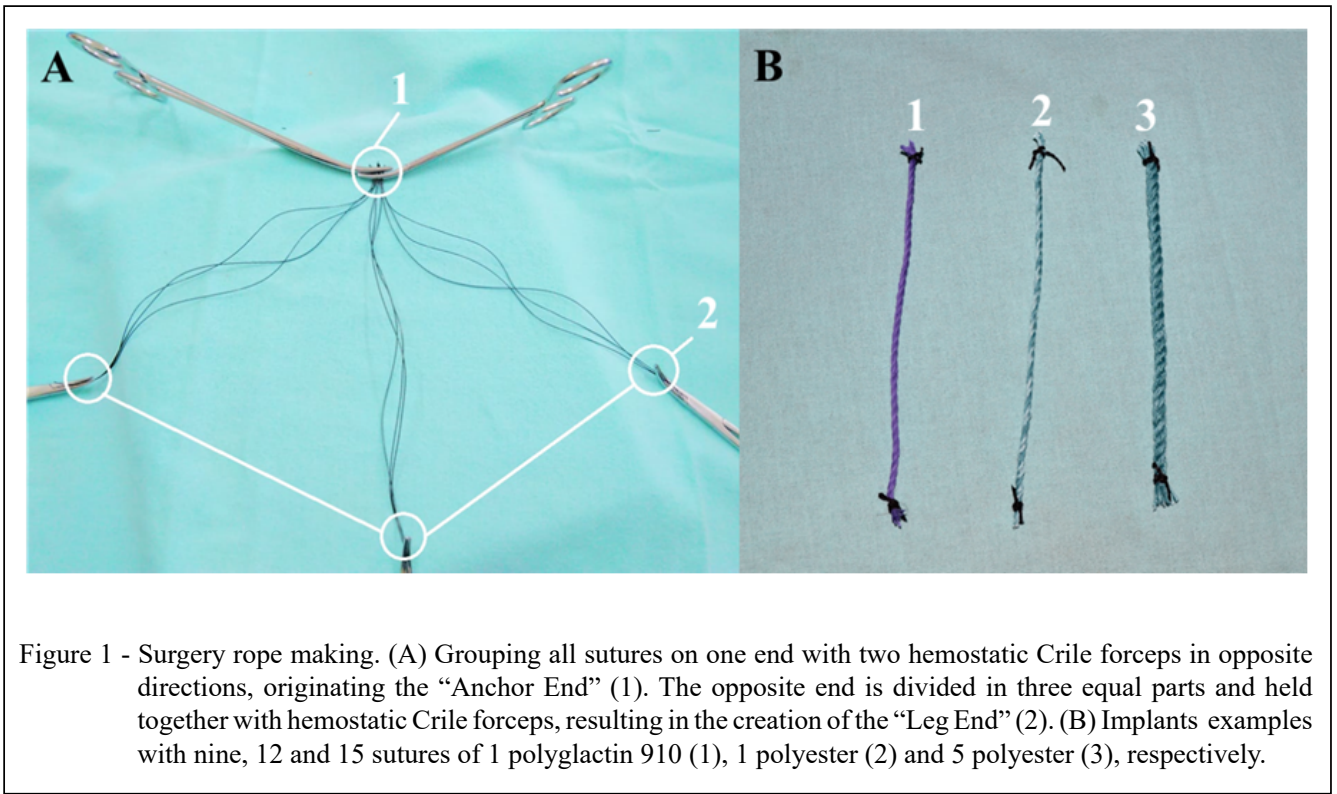

different spots: Beginning (anchor end), middle and end (leg end). The diameter of each rope was obtained from the average of these three spots. The final length (from ligature to ligature) was evaluated with the help of a ruler. The measuring were done by the same devices and researcher.

The tensile test of the 27 samples was done in the Construction Materials Lab at Universidade Federal de Santa Maria, Rio Grande do Sul, Brazil. Tensile tests were done in the tensile and compression tests press, Anmsle brand, universal model. The machine has a hydraulic load system, two conical claws, 10 ton capacity and manually controlled speed (minimum 50 kilogram per second). The ropes were fixed to a solid iron bar, which was attached to the conical claws of the press. The sample was tensioned until breaking while the press scale recorded the maximum supported load in kilogram. Afterward, the load was transformed in Newton.

\section{Data analysis}

For data analysis, the statistical package $\mathrm{SAS}^{\circledR}$, version 9.4 was used. After the normalcy test (Shapiro-Wilk) variance analysis was made. Through the MIXED procedure, the number of sutures, materials and their interactions were considered as fixed effects, and samples and residue as random effects. When differences were observed, the averages were compared using the means resource and the interactions were unfolded when significant at $5 \%$ probability.
The regression analysis between the number of sutures and the answer variables was done through the REG procedure. The correlation evaluation was done through the CORR procedure. Probability limits values of $5 \%$ were adopted for significance.

\section{RESULTS AND DISCUSSION}

There was no significant interaction between the number of sutures and type of material to load variable $(p>0.05$; Table 1). However, isolated, both factors influenced final resistance $(\mathrm{p}>0.05$; Table 1$)$.

Using nine sutures resulted in load 19.81\% lower than using 12 and 15 sutures (Table 1). Material "C" supported loads $86 \%$ and $150 \%$ higher than materials " $A$ " and "B", respectively ( $p>0.05$; Table 1$)$.

There was interaction between number of sutures and type of material for the variables length and thickness ( $p>0.05$; Table 1$)$. When nine, 12 and 15 sutures were used, the thickness was superior in material "C" (3.30, 4.00 e $4.63 \mathrm{~mm}$, respectively), intermediary in material " $A$ " $(2.34,2,80$ e $3,20 \mathrm{~mm}$, respectively) and inferior in material " $\mathrm{B}$ " $(2,23,2,43$ e 2,73 mm, respectively). The highest length was observed in material " $A$ " $(13,87,13,40$ e 13,07 cm, respectively), intermediary in material " $\mathrm{B}$ " $(13,08$, 12,63 e $12,53 \mathrm{~cm}$, respectively), and inferior in material " $C$ " (12,30, 11,17 e 10,23 cm, respectively).

Positive correlation was observed between load and thickness $(\mathrm{p}<0.01 ; \mathrm{r}=0.92)$, indicating that the higher the thickness, higher the expected final 
Table 1 - Averages according to the number of sutures and material used.

\begin{tabular}{|c|c|c|c|c|c|c|c|c|c|c|}
\hline \multirow[t]{2}{*}{ Variables } & \multicolumn{3}{|c|}{-----Number of sutures (S)----- } & \multicolumn{3}{|c|}{----Type of material (M)---- } & \multirow[t]{2}{*}{ SEM $^{*}$} & \multicolumn{3}{|c|}{------Probability-------- } \\
\hline & 9 & 12 & 15 & A & $\mathrm{B}$ & $\mathrm{C}$ & & $\mathrm{S}$ & M & $\mathrm{S}^{*} \mathrm{M}$ \\
\hline $\begin{array}{l}\text { Load }^{* *} \\
\text { (N) }\end{array}$ & $423.47 \mathrm{~b}$ & $500.3 \mathrm{a}$ & $555.89 \mathrm{a}$ & $409.83 b$ & $305.73 c$ & $764.09 \mathrm{a}$ & 20.80 & $<0.01$ & $<0.01$ & 0.34 \\
\hline $\begin{array}{l}\text { Length } \\
(\mathrm{cm})\end{array}$ & 13.08 & 12.4 & 11.94 & 13.44 & 12.74 & 11.23 & 0.12 & $<0.01$ & $<0.01$ & $<0.02$ \\
\hline $\begin{array}{l}\text { Thickness } \\
(\mathrm{mm})\end{array}$ & 2.63 & 3.08 & 3.52 & 2.79 & 2.47 & 3.98 & 0.04 & $<0.01$ & $<0.01$ & $<0.01$ \\
\hline
\end{tabular}

${ }^{*} \mathrm{SEM}=$ Standard error of the means.

${ }^{* *}$ For the load variable, distinct letters indicate statistical variation between averages.

load. Negative correlation was observed between number of sutures and length $(\mathrm{p}=0.03 ; \mathrm{r}=-0.42)$ and between load and length $(\mathrm{p}<0,01 ; \mathrm{r}=-0,77)$.

We observed significant linear regression between the number of sutures and the length $(\hat{\mathrm{Y}}$ $=14,741-0,189 ; \mathrm{p}=0,03 ; \mathrm{R}=17 \%$ ) creating a 0,189 $\mathrm{cm}$ reduction in the final implant length for each suture added to the rope. There was also linearity between number of sutures and thickness $(\hat{\mathrm{Y}}=1,300$ $+0,148 \mathrm{x} ; \mathrm{p}=0,01 ; \mathrm{R}=23 \%$ ), every suture added raised by $0,148 \mathrm{~mm}$ the final thickness of the implant. There was also linearity between load and thickness $(\hat{\mathrm{Y}}=-290,983+254,795 ; \mathrm{p}<0,01 ; \mathrm{R}=84 \%)$ indicating that for each $\mathrm{mm}$ of thickness added, a raise of $254,975 \mathrm{~N}$ in load is expected. Therefore, upon adding one suture to the rope, an increment of $37,736 \mathrm{~N}$ in final load is expected.

For material "A", significant linear regression was observed between the number of sutures and thickness $(\hat{Y}=1,122+0,139 x ; p<0,001$; $\mathrm{R}=97 \%$ ), representing a $0,139 \mathrm{~mm}$ raise in final thickness for every suture added to the implant. For implant "B", there was linear regression between number of sutures and load $(\hat{\mathrm{Y}}=1,667+25,339 \mathrm{x}$; $\mathrm{p}<0,001 ; \mathrm{R}=81 \%$ ) and between number of sutures and thickness $(\hat{\mathrm{Y}}=1,467+0,083 \mathrm{x} ; \mathrm{p}<0,001$; $\mathrm{R}=94 \%$ ). Thus, every suture added to the rope will result in a $25,339 \mathrm{~N}$ raise in load and a $0,083 \mathrm{~mm}$ raise in final thickness of the implant. There was also linear regression between load and thickness $(\hat{\mathrm{Y}}$ $=-371,675+274,625 ; \mathrm{p}<0,01 ; \mathrm{R}=70 \%$ ) indicating that each $\mathrm{mm}$ of thickness creates a $274,625 \mathrm{~N}$ raise in final load (Figure 2).

For material "C", there was linear regression between the number of sutures and length $(\hat{\mathrm{Y}}=15,367-0,344 \mathrm{x} ; \mathrm{p}<0,001 ; \mathrm{R}=94 \%)$ indicating that for every suture added to the implant, a 0,344 $\mathrm{cm}$ reduction is expected in the final length. There was also linearity between number of sutures and thickness $(\hat{\mathrm{Y}}=1,311+0,222 \mathrm{x} ; \mathrm{p}<0,001 ; \mathrm{R}=93 \%)$ indicating that every suture added to the implant results in a $0,222 \mathrm{~mm}$ raise in final thickness.

The average time of the twisting stage was $73 \mathrm{sec} \pm 39 \mathrm{sec}$. Complications such as shearing sutures between forceps were the only ones observed in this stage, not representing problems for the conclusion of the process beyond the need to restart the making of the rope.

The tested sutures were chosen because of the correspondence of diameter between " $A$ " and " $B$ " and raw material between "B" and " $\mathrm{C}$ ". The thickness and final load averages were lower in " $B$ " than " $A$ ". Moreover, the " $\mathrm{C}$ " implants resulted in the highest values (Table 1). Such results indicated that the polyglactin 910 ropes are more resistant than those of polyester, however final thickness is predictive for higher resistance.

Material "B" was the only one to obtain significant linear regression for supported load. The implants are subject to thickness variability according to the pressure applied during their making. Low tensile resistances are believed to be related to variability in suture diameter, because the places with the lowest diameter are stress concentration zones, predisposing their rupture (ALVES et al., 2017). In this sense, the variability could explain the absence of linear regression in " $A$ " and " $C$ ", as well as the noninteraction between number of sutures and type of material to the supported load (Table 1). We believed this is the study's greatest limitation.

The tissues' repair depends on multiple variables, which included the tissue characteristics, suture material properties and surgical technique used (GOMIDE et al., 2018). When using surgical sutures to recover lost articular stability, the implants must 


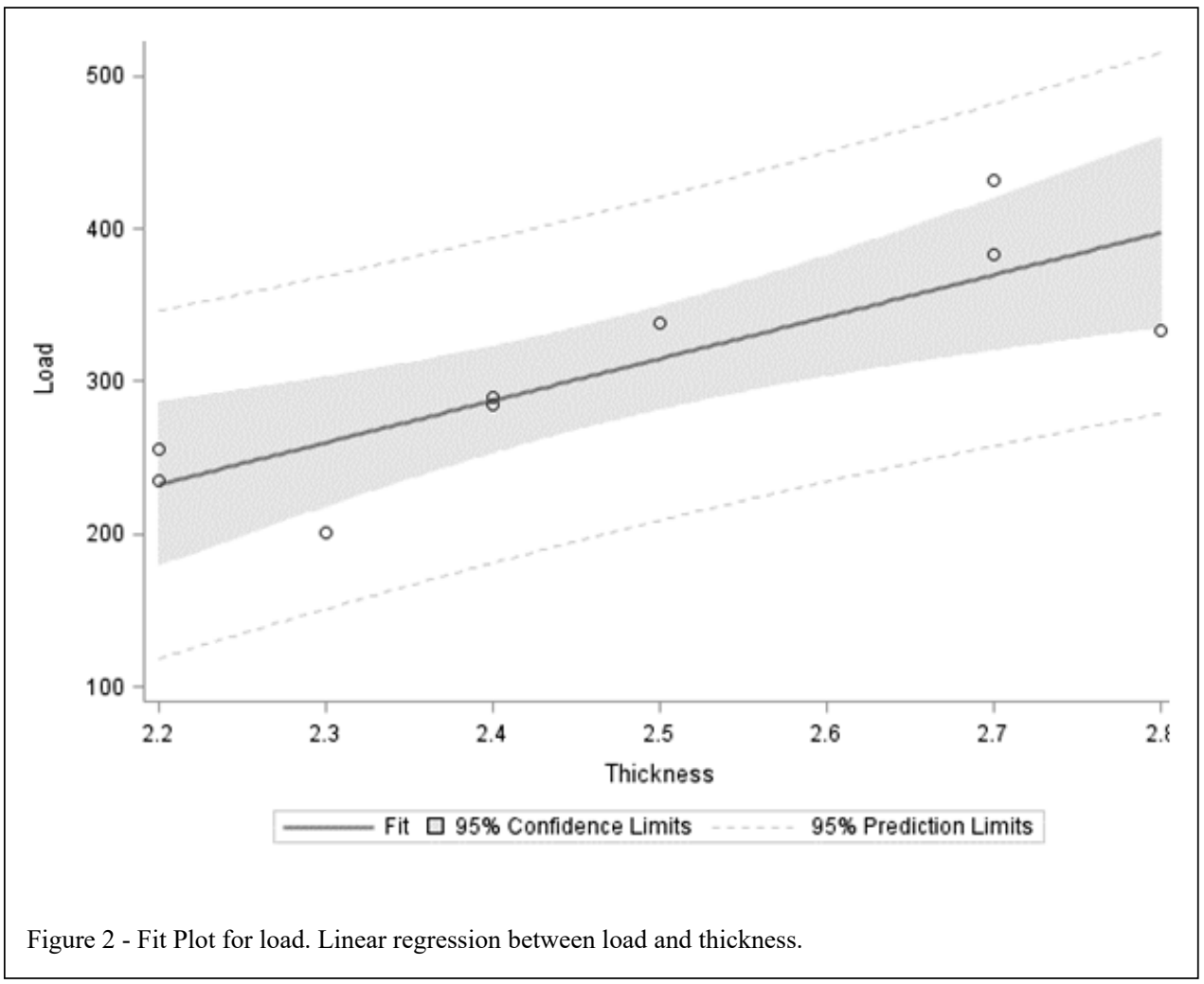

be able to resist the same tensile forces to which the original ligaments were submitted (FUKUDA et al., 1986). Thereby, previous knowledge of the structure to be replaced by the rope is imperative, allowing the estimate of number of sutures and material necessary for the making of the implant.

When bone tunnels are used to replace deficient cranial cruciate ligaments with synthetic grafts, the implants must be lengthy enough to go through the orifices (JOHNSTON \& TOBIAS, 2017). Thus, the negative correlation reported in this study between number of sutures and length must be considered during the surgical planning and rope making. The linear regression of material " $\mathrm{C}$ " (reduction of $0,344 \mathrm{~cm}$ in final implant length for every suture added) allowed the shortening of the ropes to be calculated. The thickness was linear for all groups, allowing the diameter of the drill for the bone tunnel to be estimated after the implant choice.

The TightRope Fiber Tape system is composed by synthetic multifilament and possesses high biomechanical resistance, being used for correction of cranial cruciate ligament deficiency in dogs (BISKUP et al., 2014; COOK et al., 2010). The biomechanical analysis of tensile resistance of the Fiber Tape implant resulted in an average load of $725 \mathrm{~N}$ (ROSE et al., 2012). Comparing to our data, material " $C$ " obtained superior load averages $(764,09$ $\mathrm{N})$ with average thickness of $3,98 \mathrm{~mm}$. The linearity of supported load in material "B" allows the estimate that an implant with 29 sutures will support a similar average load $(734,831 \mathrm{~N})$, resulting in a device with approximately $2,407 \mathrm{~mm}$ thickness.

\section{CONCLUSION}

We asserted that the methodology of implant making is available and the production time is short, not compromising surgical time. Confirming our hypothesis, there is interaction and positive correlation between final implant thickness and its tensile resistance. Polyester 5 reached the highest mechanical resistance loads; however, not linearly. We suggested the use of 1 polyester for the making of non absorbable implants, because it's possible to estimate the increased strength for every added suture to the implant $(25,339 \mathrm{~N})$. The use of 1 polyglactin 910 promotes load averages superior to those of 1 polyester; therefore, supporting in vivo studies with absorbable surgical rope. 


\section{ACKNOWLEDGEMENTS}

I thank all those who somehow collaborated in the execution of this study. Especially Coordenação de Aperfeiçoamento de Pessoal de Nível Superior (CAPES) and Universidade Federal de Santa Maria (UFSM) for their support in carrying out the research.

\section{DECLARATION OF CONFLICT OF INTERESTS}

The authors declare no conflict of interest. The founding sponsors had no role in the design of the study; in the collection, analyses, or interpretation of data; in the writing of the manuscript, and in the decision to publish the results.

\section{AUTHORS' CONTRIBUTIONS}

All authors contributed equally for the conception and writing of the manuscript. All authors critically revised the manuscript and approved of the final version.

\section{REFERENCES}

ALVES, A. P. et al. Biomechanics and dimensional evaluation of the suture based on chitosan. Arquivo Brasileiro de Medicina Veterinária e Zootecnia, v.69, n.4, p.896-900, Jan. 2017 Available from: <http://www.scielo.br/scielo.php?pid=S0102$09352017000400896 \&$ script $=$ sci_abstract\&tlng $=\mathrm{pt}>$. Accessed: Jul. 10, 2019. doi: 10.1590/1678-4162-9164.

ASSOCIAÇÃO BRASILEIRA DE NORMAS TÉCNICAS - ABNT NBR 13904. Fios para sutura cirúrgica. Rio de Janeiro, RJ: ABNT, maio, 2003. 15p. Available from: $<$ https://www.abntcatalogo.com.br/ norma.aspx?ID=2297>. Accessed: Jul. 10, 2019.

BARNHART, M. D. et. al. Evaluation of an intra-articular synthetic ligament for treatment of cranial cruciate ligament disease in dogs: a six-month prospective clinical trial. Veterinary and comparative orthopaedics and traumatology, v.29, n.6, p.491-498, dez. 2006. Available from: <https://www.ncbi.nlm.nih.gov/pubmed/27709221>. Accessed: Jul. 10, 2019. doi: 10.3415/VCOT-15-12-0206.

BISKUP, J. J. et. al. Ability of the tightrope1 and percutaneous Lateral Fabellar Suture Techniques to Control Cranial Tibial Translation. Veterinary surgery, v.43, n.8, p.959-965, nov. 2014. Available from: $<$ https://www.ncbi.nlm.nih.gov/pubmed/24433385>. Accessed: Jul. 10, 2019. doi: 10.1111/j.1532-950X.2013.12111.x.

BRENDOLAN, A. P. et al. Biomechanical properties of canine fascia lata and cranial cruciate ligament. Arquivo Brasileiro de Medicina Veterinária e Zootecnia, Belo Horizonte, v.53, n.1, p.27-36, 2001. Available from: <http://www.scielo.br/ scielo.php?pid $=$ S0102-09352001000100005\& script $=\mathrm{sci}$ abstract\&tlng=pt $>$. Accessed: Jul. 10, 2019. doi: 10.1590/S010209352001000100005

COOK J. L et. al. Clinical comparison of a Novel Extracapsular Stabilization Procedure and Tibial Plateau Leveling Osteotomy for Treatment of Cranial Cruciate Ligament Deficiency in Dogs. Veterinary Surgery, v.39, n.3, p.315-323, abr. 2010. Available from: $\quad<$ https://www.ncbi.nlm.nih.gov/pubmed/20345535> Accessed: Jul. 10, 2019. doi: 10.1111/j.1532-950X.2010.00658.x

FUKUDA, K. et al. Biomechanical study of the ligamentous system of the acromioclavicular joint. The Journal of bone and joint surgery. American volume, v.68, n.3, p.434-440, 1986. Available from: $<$ https://www.ncbi.nlm.nih.gov/pubmed/3949839>. Accessed: Jul. 10, 2019. doi: 10.2106/00004623-198668030-00019.

GOMIDE, L. C. et al. Estudo mecânico das propriedades dos fios de sutura usados em cirurgias ortopédicas. Revista Brasileira de Ortopedia, 2018. Available from: <https://www.sciencedirect. com/science/article/pii/S0102361617303259>. Accessed: Jul. 10, 2019. doi: 10.1016/j.rbo.2018.02.001.

JOHNSTON, S. A.; TOBIAS, K. M. Veterinary Surgery Small Animal, 2.ed. United States, Saunders, MO, 2017.

JOPP, I.; REESE, S. Morphological and biomechanical studies on the common calcaneal tendon in dogs. Veterinary and comparative orthopaedics and traumatology, v.22, n.2, p.119124, 2009. Available from: <https://www.ncbi.nlm.nih.gov/ pubmed/19290392>. Accessed: Jul. 10, 2019. doi: 10.3415/VCOT08-03-0029.

MCKENNA, H. A. et al. Handbook of Fibre Rope Technology, 1ed. The Textile Institute. North America, United States: CRC Press, 2004

MORTON, M. A. et al. Mechanical Testing of a Synthetic Canine Gastrocnemius Tendon Implant. Veterinary surgery, v.44, n.5, p.596-602, jul. 2015. Available from: <https://www.ncbi. nlm.nih.gov/pubmed/26114897>. Accessed: Jul. 10, 2019. doi: 10.1111/j.1532-950X.2015.12329.x.

MÜLLER, D. C. M. et al. Properties of polypropylene implant versus cranial cruciate ligament in dogs. Jornal Brasileiro de Cirurgia Veterinária, v.3, n.7, p.1-93, jan. 2014.

OMINI, L. et al. Innovative, intra-articular, prosthetic technique for cranial cruciate ligament reconstruction in dogs: a cadaveric study. The Journal of veterinary medical science, v. 80 , n.4, p.583-589, abr. 2018. Available from: <https://www.ncbi.nlm.nih. gov/pubmed/29459502>. Accessed: Jul. 10, 2019. doi: 10.1292/ jvms. 16-0483.

PAN, N.; BROOKSTEIN, D. Physical properties of twisted structures. Part ii: industrial yarns, cords, and ropes. Journal of Applied Polymer Science, v.83, p.610-630, 2002. Available from: $<$ https://onlinelibrary.wiley.com/doi/pdf/10.1002/app.2261>. Accessed: Jul. 10, 2019. doi: 10.1002/app.2261.

ROSE, N. D. et. al. Mechanical testing of orthopedic Suture Material Used for Extra-Articular Stabilization of Canine Cruciate Ligament-Deficient Stifles. Veterinary Surgery, v.41, n.2, p.266272, fev. 2012. Available from: <https://www.ncbi.nlm.nih.gov/ pubmed/22092233>. Accessed: Jul. 10, 2019. doi: 10.1111/j.1532950X.2011.00887.x

YILMAZ, D. et al. Packing density of compact yarns. Textile Research Journal, v.77, n.9, p.661-667, 2007. Available from: $\quad<$ https://journals.sagepub.com/doi/abs/10.1177/004051 7507078796? journalCode=trjc $>$. Accessed: Jul. 10, 2019. doi: $10.1177 / 0040517507078796$ 